University of Nebraska - Lincoln

DigitalCommons@University of Nebraska - Lincoln

\title{
ISOLATION AND CHARACTERIZATION OF A BOVINE VISCERAL ENDODERM CELL LINE DERIVED FROM A PARTHENOGENETIC BLASTOCYST
}

Neil C. Talbot

United States Department of Agriculture-Agricultural Research Service

Thomas J. Caperna

United States Department of Agriculture-Agricultural Research Service

Anne M. Powell

United States Department of Agriculture-Agricultural Research Service, anne.powell@ars.usda.gov

Alan D. Ealy

United States Department of Agriculture-Agricultural Research Service

Le Ann Blomberg

United States Department of Agriculture-Agricultural Research Service, leann.blomberg@ars.usda.gov

See next page for additional authors

Follow this and additional works at: https://digitalcommons.unl.edu/usdaarsfacpub

Part of the Agricultural Science Commons

Talbot, Neil C.; Caperna, Thomas J.; Powell, Anne M.; Ealy, Alan D.; Blomberg, Le Ann; and Garrett, Wesley M., "ISOLATION AND CHARACTERIZATION OF A BOVINE VISCERAL ENDODERM CELL LINE DERIVED FROM A PARTHENOGENETIC BLASTOCYST" (2005). Publications from USDA-ARS / UNL Faculty. 690. https://digitalcommons.unl.edu/usdaarsfacpub/690

This Article is brought to you for free and open access by the U.S. Department of Agriculture: Agricultural Research Service, Lincoln, Nebraska at DigitalCommons@University of Nebraska - Lincoln. It has been accepted for inclusion in Publications from USDA-ARS / UNL Faculty by an authorized administrator of DigitalCommons@University of Nebraska - Lincoln. 


\section{Authors}

Neil C. Talbot, Thomas J. Caperna, Anne M. Powell, Alan D. Ealy, Le Ann Blomberg, and Wesley M. Garrett 


\title{
ISOLATION AND CHARACTERIZATION OF A BOVINE VISCERAL ENDODERM CELL LINE DERIVED FROM A PARTHENOGENETIC BLASTOCYST
}

\author{
NEIL C. TALBOT, ${ }^{1}$ THOMAS J. CAPERNA, ANNE M. POWELL, ALAN D. EALY, \\ LE ANN BLOMBERG, AND WESLEY M. GARRETT
}

\begin{abstract}
U.S. Department of Agriculture, Agricultural Research Service, Animal and Natural Resources Institute, Biotechnology and Germplasm Laboratory (N. C. T., A. M. P., L. A. B., W. M. G.) and Growth Biology Laboratory, Beltsville Agricultural Research Center, Beltsville, Maryland 20705 (T. J. C.), and Department of Animal Sciences, University of Florida, Gainesville, Florida 32611-0910 (A. D. E.).
\end{abstract}

(Received 16 September 2004; accepted 24 March 2005)

\begin{abstract}
SUMMARY
A cell line, BPE-1, was derived from a parthenogenetic 8-d in vitro-produced bovine blastocyst that produced a cell outgrowth on STO feeder cells. The BPE-1 cells resembled visceral endoderm previously cultured from blastocysts produced by in vitro fertilization (IVF). Analysis of the BPE-1 cells demonstrated that they produced serum proteins and were negative for interferon-tau production (a marker of trophectoderm). Transmission electron microscopy revealed that the cells were a polarized epithelium connected by complex junctions resembling tight junctions in conjunction with desmosomes. Rough endoplasmic reticulum was prominent within the cells as were lipid vacuoles. Immunocytochemistry indicated the BPE-1 cells had robust microtubule networks. These cells have been grown for over 2 yr for multiple passages at 1:10 or 1:20 split ratios on STO feeder cells. The BPE-1 cell line presumably arose from embryonic cells that became diploid soon after parthenogenetic activation and development of the early embryo. However, metaphase spreads prepared at passage 41 indicated that the cell population had a hypodiploid $(2 n=60)$ unimodal chromosome content with a mode of 53 and a median and mean of 52 . The cell line will be of interest for functional comparisons with bovine endoderm cell lines derived from IVF and nuclear transfer embryos.
\end{abstract}

Key words: bovine; cell; line; parthenogenic; endoderm.

\section{INTRODUCTION}

In vitro models of bovine extraembryonic visceral endoderm are important for the study of mechanisms of preimplantation bovine embryo development. Visceral or yolk sac endoderm cells derive from the primitive endoderm or hypoblast (Kadokawa et al., 1987) and form the yolk sac, which is ventral to the early bovine embryo (embryonic disc) and is adjacent to, and continuous with, the inner aspect of the trophectoderm as it rapidly expands to form the filamentous blastocyst stage by $3 \mathrm{wk}$ postfertilization (Chang, 1952; Carlson, 1981; Rüsse et al., 1992). As gastrulation proceeds, mesoderm cells delaminate from the embryonic disc and rapidly cover the visceral endoderm epithelial sheet (splanchnic mesoderm) so as to contribute to a vascular network that develops within the yolk sac tissue (Carlson, 1981; Rüsse et al., 1992). The yolk sac persists for several weeks until the chorioallantoic membranes are established. After this time, it rapidly shrinks in size, and the remnant is finally absorbed into the belly stalk of the fetus (Carlson, 1981; Mossman, 1987).

Although the yolk sac of mammals is referred to as a vestigial

\footnotetext{
' To whom correspondence should be addressed at E-mail: ntalbot@anri. barc.usda.gov

Disclaimer: Mention of trade names or commercial products in this publication is solely for the purpose of providing specific information and does not imply recommendation or endorsement by the U.S. Department of Agriculture.
}

structure, because no yolk is actually present for the tissue layer to surround, it carries out various important functions in the developing embryo during the preimplantation and periimplantation periods of pigs and ruminants (Carlson, 1981; Mossman, 1987; Rüsse et al., 1992). The yolk sac epithelial layer is in direct contact with an extensive area of the chorion (trophectoderm), and this in close apposition to the uterine endometrium, is positioned to facilitate nutrient transport from the uterus to the embryo and early fetus (Carlson, 1981; Mossman, 1987). The yolk sac also supports the early development of the fetus by producing a spectrum of serum proteins (Janzen et al., 1982; Young and Klein, 1983; Shi et al., 1985) and functions as the site of early blood cell formation (Rüsse et al., 1992; Niimi et al., 2002). These functions are of particular importance to the cow because formation of the placenta is delayed until after approximately $40 \mathrm{~d}$ of gestation (Chang, 1952). The yolk sac, therefore, has the specialized function of supporting the early development of the fetus until further nutrient and physiological support is taken over by the formation of the chorioallantosis and its connection with the uterus, i.e., placentation (Carlson, 1981; Rüsse et al., 1992).

In vitro cell culture models of bovine visceral endoderm may be useful in the study of bovine early embryonic and periimplantation development and survival. Recently, in vitro cell culture models of bovine endoderm were reported (Talbot et al., 2000a). Morphological features of bovine endoderm cells continuously cultured in vitro were similar to those found in vivo, and the cells also showed in 
vivo functional characteristics such as serum-protein secretion (Talbot et al., 2000a). Although in vitro models of visceral endoderm exist for the mouse (Walter et al., 1984; Adamson et al., 1985; Mummery et al., 1991) and human (Pera et al., 1987), the greatly delayed implantation of ruminant embryos and the extensive size of the bovine yolk sac suggest that the function of the ruminant yolk sac may be more vital for bovine embryo survival than in the mouse or human (Carlson, 1981; Rüsse et al., 1992). Thus, bovine visceral endoderm cell lines may offer a more relevant in vitro cellular substrate with which to study yolk sac function and mechanisms of preimplantation embryo survival in ruminants.

Given this, models of bovine yolk sac endoderm may help illuminate differences between embryos created by somatic cell nuclear transfer (NT) and embryos derived from normal fertilization of eggs with sperm. This is particularly relevant because preimplantation embryo survival appears to be a critical problem with NT pregnancy establishment (Hill et al., 2000; De Sousa et al., 2001; Hashizume et al., 2002). For the comparative study of mechanisms of developmental failure in NT pregnancies, an in vitro model of endoderm derived from a source of bovine embryos that never successfully implant and that have deficiencies in their extraembryonic membrane form and function would be useful. Endoderm cell lines derived from parthenogenetic bovine embryos might provide such a comparative model because, in the mouse, parthenogenetic embryos are characterized by poor development of their extraembryonic membranes and they uniformly fail to maintain pregnancy (Surani and Barton, 1983; Surani et al., 1990). Much of the developmental failure in parthenogenotes is thought to arise from their lack of paternally imprinted genes (Surani et al., 1990) and, similarly, the aberrant gene expression that occurs after cloning, some in imprinted genes, may be the causes of the high incidence of pregnancy failure in NT embryos (Humpherys et al., 2002; Inoue et al., 2002). Although mammalian parthenogenote-derived cell lines are rare, they have been established from mouse embryos either in the form of embryonic stem cell lines (Kaufman et al., 1983) or in the form of embryonic fibroblast secondary cell cultures (Kharroubi et al., 2001).

The isolation of an endoderm cell line from a parthenogenetic 8-d bovine blastocyst is described. The continuous culture and characterization of the cell line were undertaken to demonstrate their basic similarity to or differences from another endoderm cell line previously isolated from a blastocyst produced by in vitro fertilization (IVF) (Talbot et al., 2000a).

\section{Materials AND Methods}

Cell culture. All cells were grown on tissue culture plasticware (Nunc, Roskilde, Denmark; and Falcon, Becton Dickinson, Lincoln Park, NJ). Cryovials $(2 \mathrm{ml})$ were purchased from Nunc. Fetal bovine serum (FBS) was obtained from Hyclone (Logan, UT). Cell culture reagents, including Dulbecco phosphate-buffered saline (PBS) without $\mathrm{Ca}^{++}$and $\mathrm{Mg}^{++}$, media, trypsin-ethylenediaminetetraacetic acid (EDTA) (0.05\% trypsin, $0.43 \mathrm{~m} M$ EDTA), antibiotics, nonessential amino acids, and L-glutamine were purchased from InVitrogen Corporation, Gaithersburg, MD (GIBCO). The STO cells (CRL 1503, American Type Culture Collection, Rockville, MD) were grown in Dulbecco modified Eagle medium (DMEM) with high glucose (4.5 g/L) supplemented with $10 \%$ FBS (10\% DMEM). Feeder layers were prepared by exposing a suspension of STO cells to $8 \mathrm{krad}$ gamma radiation and plating the cells at $6 \times 10^{4} \mathrm{cells} / \mathrm{cm}^{2}$. Feeder layers were maintained by refeeding with 10\% DMEM every 6-7 d.

A primary bovine parthenogenetic endoderm (BPE-1) culture was initiated from a day-8, blastocyst-stage, parthenogenetic embryo, created as described previously (Talbot et al., 2000b), by pressing it onto the STO feeder cell monolayer and plastic with a hypodermic needle, as described previously (Talbot et al., 2000a). No epiblast or trophectoderm contamination was observed in the colony outgrowth that occurred over the first 2 wk of primary culture. After $3 \mathrm{wk}$ of primary culture, the colony, then approximately $1 \mathrm{~cm}$ in diameter, was passaged for secondary culture. This first passage was accomplished by chopping the primary colony into small pieces using two hypodermic needles and transferring the resulting clumps of BPE- 1 cells into a T25 flask containing a STO feeder cell layer. The culture, henceforth, was passaged by physical disruption of the BPE-1 monolayer (as described previously in Talbot et al., 2000a) approximately every $3 \mathrm{wk}$ at a 1:3 split ratio onto fresh STO feeder layers. BPE-1 cells were cultured in DMEM/199 medium (50/50) with $10 \%$ FBS (Talbot et al., 2000a) until passage 24. Subsequent passages were cultured in $10 \%$ DMEM.

BPE-1 cell growth assays. Growth of the BPE-1 cells was assayed macroscopically by photodocumentation of sister flasks of the culture that were simultaneously fixed and stained at progressively longer time points postpassage. Fixation and staining of the cultures were performed by aspirating the medium from the flasks and immediately replacing it with a fixing-staining solution of $0.125 \%$ Coomassie Blue R-250 (InVitrogen/GIBCO), 50\% methanol, and $10 \%$ acetic acid for 10 min. The staining solution was decanted, and the cell monolayer was rinsed with distilled water to stop cell staining. If necessary, the stained cells were destained to varying degrees with a solution of $50 \%$ methanol and $10 \%$ acetic acid.

BPE-1 cell growth was assayed at passage 36 by counting the increase in the total cells per T25 flask over a 3 -wk period at 4-d intervals postpassage. Duplicate T25 flasks were counted at each time interval. Single cell suspensions of the contents of each flask were produced by washing the cells once with $2 \mathrm{ml}$ of $2 \mathrm{M}$ urea. The cells were incubated at $\sim 35^{\circ} \mathrm{C}$ in the residual urea left behind after aspiration $(\sim 0.2 \mathrm{ml})$ for $5-6 \mathrm{~min}$. One-half milliliter of trypsin-EDTA was added to each T25 flask to finish dissociation of the cells during a further $10 \mathrm{~min}$ incubation at $\sim 35^{\circ} \mathrm{C}$. The cells were suspended to a total volume of $2 \mathrm{ml}$ for cell counts in 10\% DMEM. Total cells per T25 flask was ascertained by averaging the counts of 16 hemocytometer squares $\left(1 \mathrm{~mm}^{2}\right)$. Input of the number of BPE-1 cells at the start of the growth assay was undefined, but was a 1:40 split ratio from a nearly confluent stock culture. The STO feeder cells surviving the urea-trypsin-EDTA dissociation were similarly enumerated from a parallel group of feeder cell T25 flasks that had not received any BPE-1 cell input.

Cytogenetic analysis. BPE-1 cells were analyzed for chromosome content at passage 41 . The BPE-1 cells were harvested to single cells by treatment with $2 M$ urea and trypsin-EDTA as previously described to prepare metaphase spreads (Talbot et al., 2000a). Metaphase spreads on replicate slides were stained with $1 \mu \mathrm{g} / \mathrm{ml}$ propidium iodide (PI; Molecular Probes, Eugene, $\mathrm{OR}$ ) and $2 \mu \mathrm{g} / \mathrm{ml}$ bisbenzimide (Hoechst 33342; Molecular Probes) for fluorescent observation. For chromosome counts, PI-stained metaphase spreads were imaged at $\sim \times 1000$ magnification using a Zeiss LSM 410 confocal microscope equipped with a $\times 63 \mathrm{C}$-Apochromat 1.2 numerical aperture water immersion objective. For Hoechst 33342 fluorescent observation, the 351-nm line of a Coherent Innova 90 laser was used for excitation, and the emitted light was passed through a long-pass 397-nm filter. The 568-nm line of an argon-krypton laser was used for excitation of PI, and emitted light was filtered through a long-pass 590-nm emission filter. Approximately 50 BPE1 metaphase spreads were counted for chromosome content. Approximately 30 metaphase spreads from a bovine fetal fibroblast (BFF) cell culture at passage 4 were counted as a comparative control.

Antiviral interferon-tau activity assay. Antiviral assays of the conditioned medium (CM) of BPE-1 were completed as described by Roberts et al., 1989. BPE-1 cells were assayed at passage 17 , where the 4-d CM was serum-free (SF) DMEM + 1 ITS (insulin [10 $\mu \mu \mathrm{g} / \mathrm{ml}]$, transferrin $[5.5 \mu \mathrm{g} / \mathrm{ml}]$, and selenium [0.005 $\mu \mathrm{g} / \mathrm{ml}]$; Sigma Chemical Co., St. Louis, MO). The CM from STO feeder cells alone and unconditioned medium were assayed as negative controls. The ability of samples to prevent virus-induced cell lysis by $50 \%$ was compared with a recombinant human interferon-alphaA standard (Calbiochem, La Jolla, CA; $3.84 \times 10^{8} \mathrm{IU} / \mathrm{mg}$ ). The concentration of interferontau (IFN- $\tau$ ) in CM was calculated on the basis of the specific activity of recombinant bovine IFN- $\tau\left(2.52 \pm 0.49 \times 10^{8} \mathrm{IU} / \mathrm{mg}\right)$ included in each assay. Assays were completed in duplicate, and results were reported in international units of IFN- $\tau$ per milliliter of culture medium and in nanogram per milliliter. The assay had a sensitivity of $20 \mathrm{IU} / \mathrm{ml}$.

Immunoblot analysis of CM. Western blots and immunoprobing of the blots with antitransferrin antibody were done as described previously (Talbot et 
al., 2000a). Three milliliters of SF medium (DMEM high glucose) was conditioned for $72 \mathrm{~h}$ by confluent monolayers of passage 42 BPE-1 cells (T25 flask) that had been washed $4 \times$ with SF medium. The washes were performed to remove traces of serum proteins left behind by the FBS-containing growth medium routinely used in the propagation and maintenance of the cell culture. The CM samples were centrifuged at $500 \times g$ for 15 min to pellet cell debris, and supernatants were stored frozen at $-20^{\circ} \mathrm{C}$. Serum-free medium conditioned by STO feeder cells alone, a bovine parthenogenetic trophectoderm cell culture, the CE-2B bovine endoderm cell line (Talbot et al., 2000a), and adult bovine serum (ABS) were assayed as comparative controls. The CM samples $(1 \times, 30 \mu \mathrm{l}$ of each) and ABS $(0.1 \mu \mathrm{l})$ were mixed 3:1 with $4 \times$ loading buffer containing sodium dodecyl sulfate (SDS) and $\beta$-mercaptoethanol. Samples were loaded onto $8 \%$ polyacrylamide gels, and electrophoresis (polyacrylamide gel electrophoresis [PAGE]) was performed as described by Laemmli, 1970. Proteins were transferred to polyvinylidene fluoride (PVDF) membranes (Bio-Rad, Hercules, CA), blocked with porcine albumin, and probed with polyclonal rabbit antisera to bovine transferrin (Axell Accurate, Westbury, NY). Specific immunoreactive proteins were observed by reaction with alkaline phosphatase-conjugated secondary anti-rabbit antibody, followed by the addition of nitro-blue tetrazolium chloride/5-bromo-4-chloro-3' indolylphosphate p-toluidine (NBT/BCIP) reagents (Sigma). For total protein staining, parallel blots were stained with $0.015 \%$ Coomassie Blue R-250 (Bio-Rad) in 40\% methanol and 5\% acetic acid.

Immunocytochemistry. BPE-1 cells at passage 43 and CE-2B cells (bovine visceral endoderm cell line previously derived from a blastocyst produced by IVF; Talbot et al., 2000a) at passage 4 were grown in T25 flasks and were fixed for $25 \mathrm{~min}$ in $4 \%$ methanol-free formaldehyde in PBS. The bottoms of the flasks were cut out and processed for immunocytochemistry as described previously (Talbot et al., 2003) using antibodies to alpha-tubulin (1:1000; Sigma) and beta-tubulin antibody (1:500; Sigma) mixed together. Alexa 488labeled goat anti-mouse secondary antibody (Molecular Probes) was used to detect binding of the primary antibody. The actin cytoskeleton was stained with AlexaFluor 594 phalloidin (Molecular Probes) at $2 \mathrm{U} / \mathrm{ml}(66 \mathrm{nM})$. Cell nuclei were counterstained with $500 \mathrm{ng} / \mathrm{ml}$ bisbenzimide (Hoechst 33342; Molecular Probes), and the specimens were mounted in Vectashield (Vector Labs, Burlingame, CA).

Transmission electron microscopy. Transmission electron microscopy (TEM) sample preparation and photomicroscopy were done with the assistance of JFE Enterprises, Brookeville, MD as described previously (Talbot et al., 2000a). Ultrastructural analysis was performed on samples processed from one T25 flask culture that was 3 -wk postpassage at passage 34 .

\section{REsults}

Establishment of the BPE-1 cell line. A primary outgrowth of bovine endoderm was initiated from a bovine parthenogenote that had reached the blastocyst stage after $8 \mathrm{~d}$ of egg culture. The endoderm outgrowth was recognized as such by its distinct cell and colony morphology (Talbot et al., 2000a). Also, on the basis of microscopic observation of cell and colony morphology, no trophoblast or epiblast contamination was present in the primary culture. Although it was unusual to find no trophoblast contamination in the primary culture, an absence of trophectoderm was observed in 3 of 111 parthenogenetic whole bovine blastocyst explant cultures or $\sim 3 \%$ in an unrelated study involving similar primary blastocyst cultures (unpublished data; N. C. Talbot). Epiblast survival in whole bovine blastocyst explant cultures is more rare (less than $1 \%$; unpublished observation; N. C. Talbot) and did not occur in this case. This lack of contaminating cell types simplified the establishment of the bovine parthenogenetic endoderm culture. The culture was designated BPE-1.

The primary BPE-1 colony was composed of approximately cuboidal epithelial cells closely packed together in the center of the colony, with flatter and more spread out cells at the periphery of the colony. The primary colony had frequent domes or areas of cells that formed vesicle-like structures by transporting fluid between two or three adjacent cells. The cells were not as granular in appearance

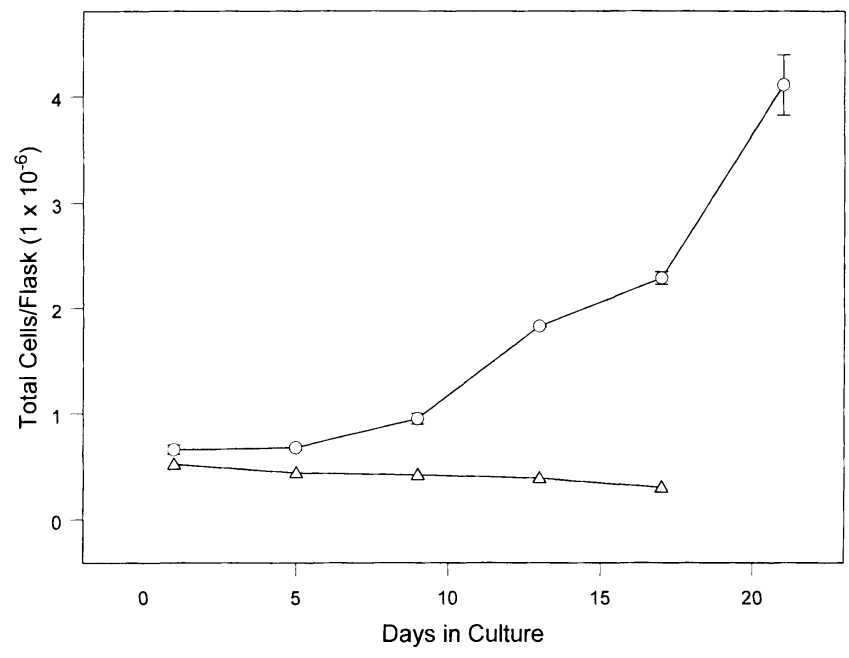

FIc. 1. Growth curve of BPE-1 cells assayed at passage 36. Total of BPE-1 and nondividing STO feeder cells $(\bigcirc)$. STO feeder cells only $(\triangle)$.

as trophectoderm cells and had scant amounts of visible lipid. In addition, at the periphery of colonies or where domes occurred, distinct web-like arrangements of phase-contrast, dark cytoskeletal fibers were observed in the cells (as in Fig. 3). The cells grew predominantly on top of the STO feeder cells.

Secondary culture of the BPE-1 cells was performed after $3 \mathrm{wk}$ when the colony had reached a size of approximately $1 \mathrm{~cm}$ in diameter. Clumps of BPE-1 cells that attached in the first $24 \mathrm{~h}$ grew into $\sim 1$-cm-diameter colonies over 3-4 wk of culture. The BPE-1 cell culture grew relatively slowly during the initial secondary culture period (the first 5-10 passages); however, after this "establishment period," the secondary culture grew more quickly and was routinely passaged at 1:20 or 1:40 split ratios. After establishment, the cell line had a characteristic lag period of about 1 wk postpassage that was followed by a population doubling time of approximately 96 h (Figs. 1 and 2). The BPE-1 cell culture did not require colony cloning to maintain the purity of the visceral endoderm population, as putative parietal endoderm differentiation was not observed during the establishment of the cell line (Talbot et al., 2000a).

Similar to the primary culture, the established BPE-1 cell line formed monolayers composed of approximately cuboidal epithelial cells where most of the cells were closely packed together but did have some areas where the cells were flatter and more spread out (Fig. 3). Domes or vesicle-like structures, formed by adjacent cells transporting fluid between themselves, were common in the BPE-1 monolayer (Fig. 3). In contrast to the primary culture, later passage BPE-1 cells had cell-associated lipid droplets that were easily discernible by phase-contrast microscopy. As in the primary culture, later passage BPE-1 cells were found to have distinctive phasecontrast, dark, web-like cytoskeletal elements that traversed the cytoplasm and encircled the nucleus (Fig. 3). These cytoskeletal elements were positive for reaction with antitubulin antibody by immunocytochemical assay (Fig. $4 A$ ) and were, therefore, microtubules. In comparison, similar robust microtubule arrays were also found in the cells of the CE-2B visceral endoderm cell line (Fig. $4 B$ ), previously isolated from a bovine embryo produced by IVF (Talbot et al., 2000a), and were similar to those found in the endoderm cells lining the interior of an 11-d in vivo porcine blastocyst 


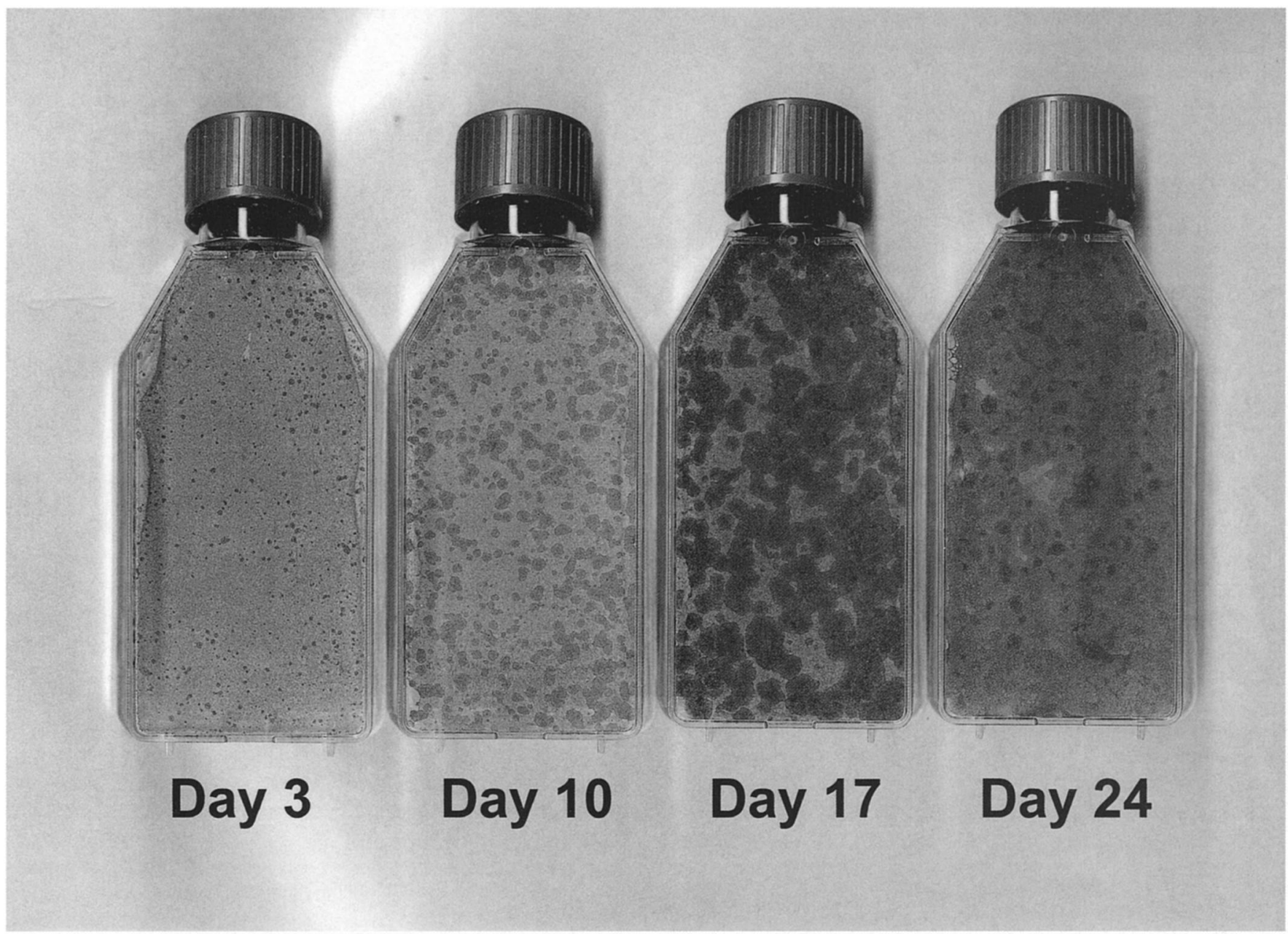

FIG. 2. Growth of BPE-1 cells shown in a cohort of T25 flasks after passage at a 1:20 split ratio at passage 38. Individual flasks were sequentially fixed and stained with Coomassie Blue R-250 over a 24-d postpassage culture period to illustrate the growth of the cells.

(Fig. $4 C$ ). The actin cytoskeleton, although occurring in the cytoplasm of the cells and perhaps colocalizing with the microtubule network, was most distinctly present at the cell boundaries in all cases (Fig. 4D-F).

Transmission electron microscopic analysis of the BPE-1 cell line. BPE-1 cells were arranged in a single layer of elongated cuboidal cells growing on top of or between the STO feeder cells (Fig. 5A). Although the BPE-1 cells were never intimately joined to the STO feeder cells, they were usually in close proximity to the STO cells, except in the case where dome formation occurred. Prominent and numerous microvilli at the apical surface (facing the medium) marked the polarized morphology of the BPE-1 cells, and the cells were joined by numerous desmosomal elements and tight junctional complexes at their lateral surfaces (Fig. 6A). Smooth and rough endoplasmic reticulum, lysosomes or digestive vacuoles, and lipid vacuoles were all numerous and well represented in the BPE-1 cells (Fig. 6B). Golgi complexes, although present, were not particularly numerous in the BPE-1 cells analyzed by TEM. Overall, the BPE-1 cells were similar in ultrastructure presentation to the in vivo endoderm cells of a 19-d expanded bovine blastocyst that was also examined by TEM (Fig. $5 B$ ).

Cytogenetic analysis of the BPE-1 cells. Figure 7 shows the dis- tribution of chromosome counts found from the enumeration of 48 BPE-1 metaphase spreads at passage 41. A unimodal distribution was found in which the majority (85\%) of BPE-1 cells were hypodiploid and contained between 47 and 56 chromosomes (Fig. 7A). The remaining $15 \%$ of metaphase spreads consisted of cells with various hypo- and hyperdiploid contents or near triploid cells (Fig. $7 A$ ). All the chromosomes were acrocentrics or telocentrics with the exception of the X-chromosome, which was submetacentric, and of which there appeared to be two (Fig. 8). As a comparative control, secondary cultures of bovine fetal fibroblast were assayed at passage 4. Of $30 \mathrm{BFF}$ metaphase spreads examined, $80 \%$ were diploid containing a full complement of 60 chromosomes (Fig. $7 B$ ). The remaining BFF metaphase spreads were either near diploid or near tetraploid (Fig. 7B).

Protein expression by BPE-I cells. Visceral endoderm is known to synthesize and secrete serum proteins (Young and Klein, 1983; Shi et al., 1985), whereas trophectoderm, the other differentiated epithelium of the early blastocyst, specifically secretes IFN- $\tau$ (Roberts et al., 1989). The medium conditioned by BPE-1 for $96 \mathrm{~h}$ was tested for IFN- $\tau$ by antiviral assay and found to have less than $20 \mathrm{IU} / \mathrm{ml}$ of IFN- $\tau$, i.e., the level was at the limit of sensitivity of the assay. Therefore, the BPE-1 cells were not secreting detectable amounts of IFN- $\tau$. 


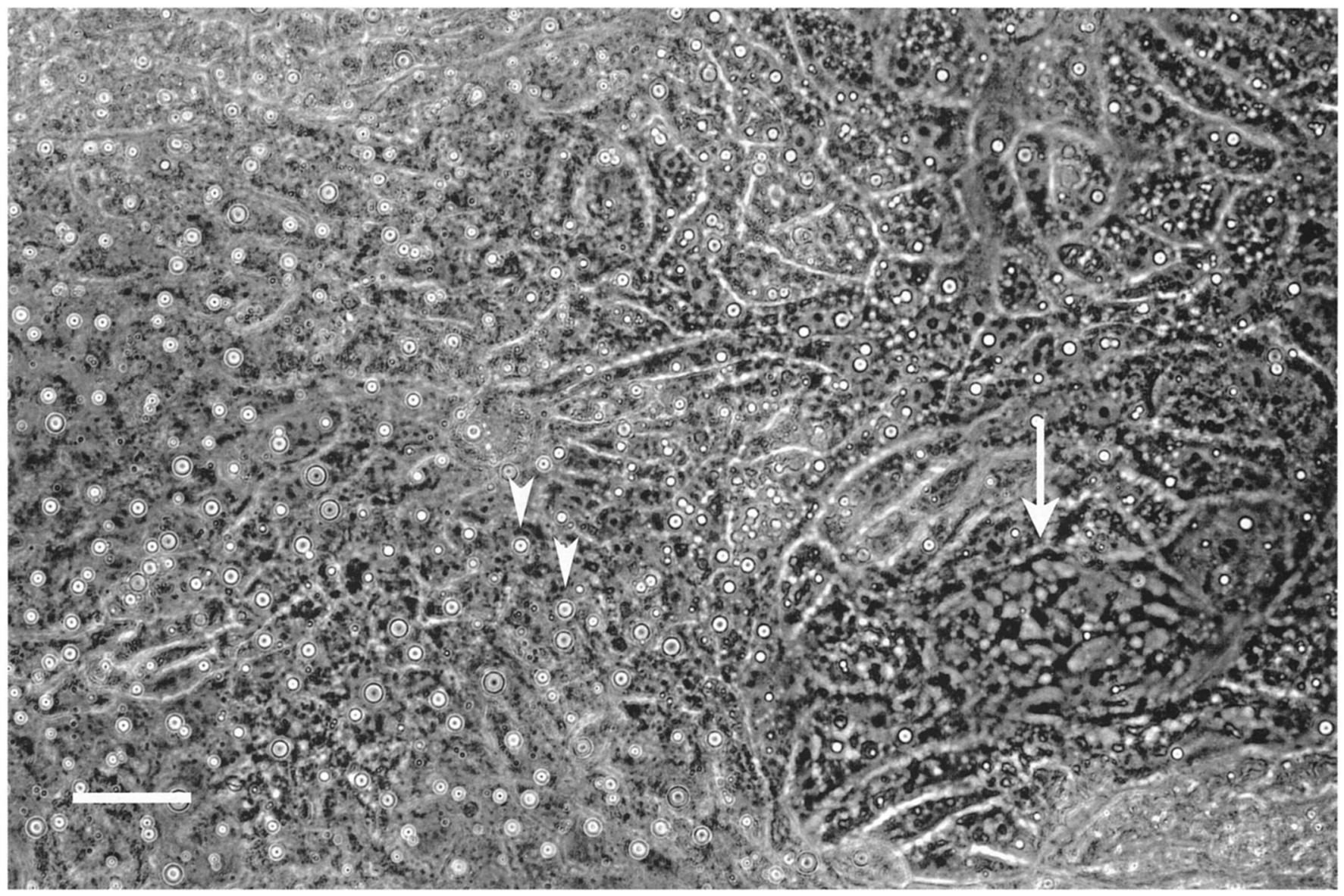

FIG. 3. Phase-contrast light micrograph of a monolayer of BPE-1 cells at passage 42 . Note the characteristic cell associated lipid droplets found in many of the cells in the monolayer (arrowheads) and the characteristic web-like cytoskeletal elements within the larger cells (arrow). Bar, $40 \mu \mathrm{m}$.

BPE-1 cells were assayed for their secretion of serum proteins, particularly, the serum protein transferrin. A Western blot of samples of SF media conditioned by either BPE-1 cells, CE-2B cells, a bovine parthenogenetic trophectoderm cell culture, or STO feeder cells only was analyzed for transferrin content by probing with antitransferrin antibody. A protein with a molecular weight equal to that of transferrin $(\sim 78 \mathrm{kDa})$ was detected by the antibody in the BPE-1 CM (Fig. 9A, lane 3) and in the CM of the CE-2B cell line (Fig. 9A, lane 4) but not in the STO feeder cell CM or trophectoderm culture CM (Fig. 9A, lanes 2 and 5, respectively). Coomassie Blue staining for the total proteins in CM separated by one-dimensional SDS-PAGE showed that the BPE-1 culture was secreting a spectrum of proteins similar to that found in bovine serum (Fig. 9B, lane 3). In comparison, the $\mathrm{CM}$ of the IVF-derived $\mathrm{CE}-2 \mathrm{~B}$ bovine endoderm cell line also showed a serum protein-like profile (Fig. 9B, lane 4), whereas CM from STO feeder cells alone, or a bovine parthenogenetic trophectoderm cell culture, did not (Fig. 9B, lanes 2 and 5, respectively). The Coomassie Blue total protein staining indicated that the transferrin was abundantly expressed by both the parthenogenetic-derived (BPE-1; lane 3) and the IVF-derived (CE-2B; lane 4) cell lines. Also, the lack of any prominent protein bands at $\sim 68 \mathrm{kDa}$ in lanes 2 and 5 of Fig. $9 B$ indicated an absence of serum protein contamination in the CM.

\section{DISCUSSION}

The study demonstrates that a parthenogenetic bovine endoderm cell culture could be readily established in long-term culture. This might not have been assumed, because a striking feature of mouse gynogenotes/parthenogenotes development in vivo is poor development and degeneration of the extraembryonic membranes (Surani et al., 1990; Tada and Takagi, 1992). However, ruminant extraembryonic tissue development is distinctly different from the mouse (Chang, 1952; Mossman, 1987). Studies of in vivo development of parthenogenotes in sheep indicated either no gross extraembryonic tissue abnormalities (Loi et al., 1998) or some hypertrophy and hypervascularization in the tissue (Hagemann et al., 1998). Also, because cell growth in culture is without the complex interdependent interaction found in vivo, the establishment of continuous cell cultures from uniparental tissue sources is perhaps not surprising (Kaufman et al., 1983; Kharroubi et al., 2001). Because the BPE-1 cells have been continuously cultured for nearly $3 \mathrm{yr}$ and for greater than 45 passages, usually at high split ratios, it is probable that the culture is immortalized and is a cell line.

It was unusual not to find trophoblast contamination in the primary blastocyst explant culture that gave rise to BPE-1, but this is unnecessary for the establishment of the endoderm cultures. In an 

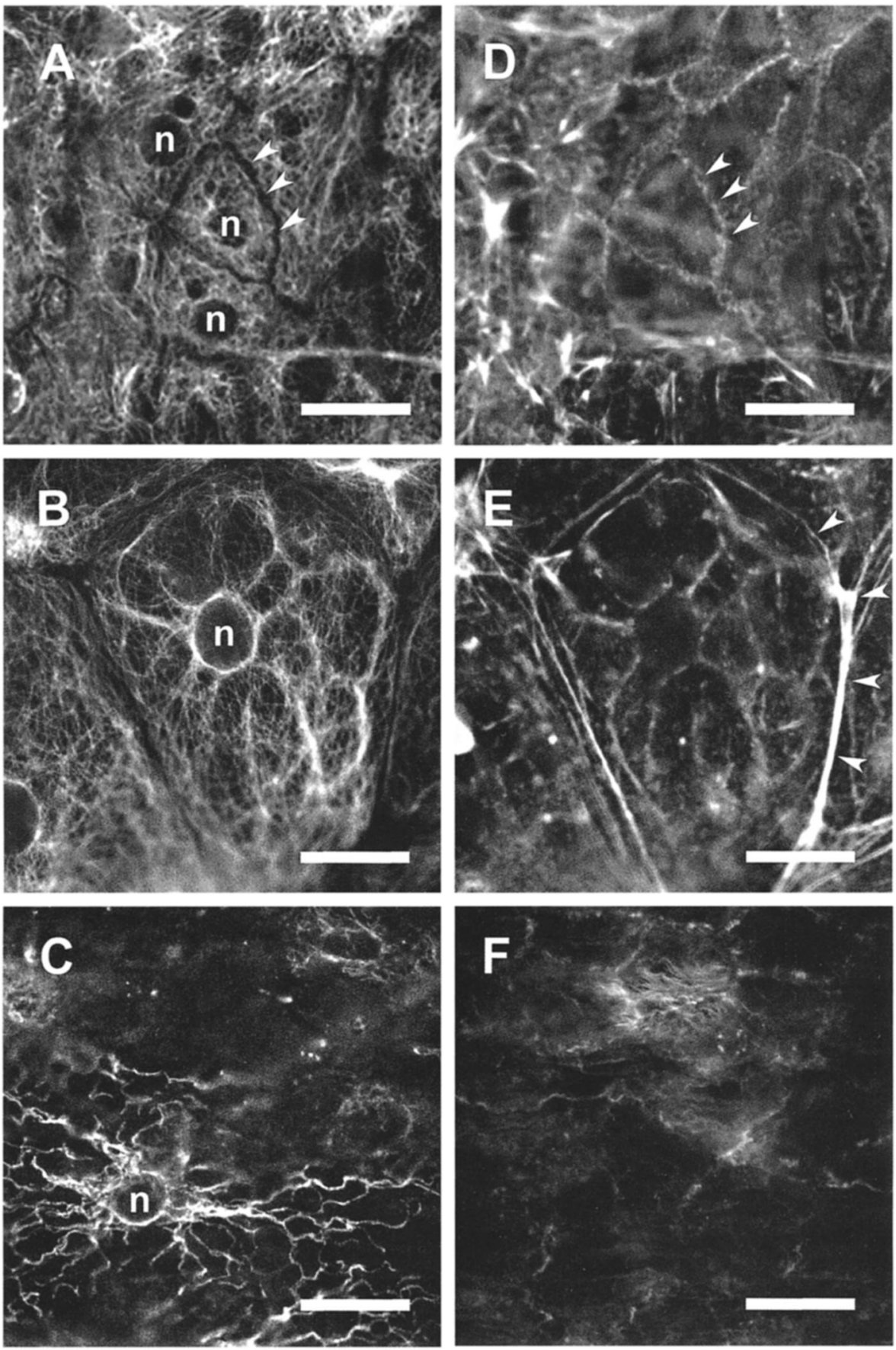

FIG. 4. Fluorescent staining of alpha/beta tubulin and actin in BPE- 1 and CE-2B cell lines. Characteristic web-like array of microtubule (tubulin) cytoskeletal elements that ramify the cell and surround the nucleus in BPE-l cells $(A)$, CE-2B cells $(B)$ or the endoderm cells lining the interior of an 11-d in vivo porcine blastocyst $(C)$. Bar, $25 \mu \mathrm{m}$. Corresponding Phalloidin staining of the actin cytoskeleton in BPE-1 cells $(D)$, CE-2B cells $(E)$, or in vivo porcine endoderm cells $(F)$. Bar, $25 \mu \mathrm{m}$. Arrowheads indicate borders of cells; n, nucleus.

unrelated study, it was found that parthenogenetic whole bovine blastocyst explant cultures produced endoderm outgrowth at high rates but that most were contaminated by the coincident outgrowth of trophectoderm cells (unpublished observation; N. C. Talbot). This presents little problem in establishing the parthenogenetic endoderm culture in pure form because the trophectoderm outgrowth can be readily removed. Trophectoderm outgrowths, recognized by their distinct cell and colony morphology, can be detached from the endoderm cells and the plastic substrate using 25-gauge hypodermic needles for dissection and a glass micropipette to aspirate the trophectoderm cells from the culture. This is efficient because the trophectoderm forms a continuous sheet of cells that are strongly connected to one another, and the endoderm does not adhere to the trophectoderm. 

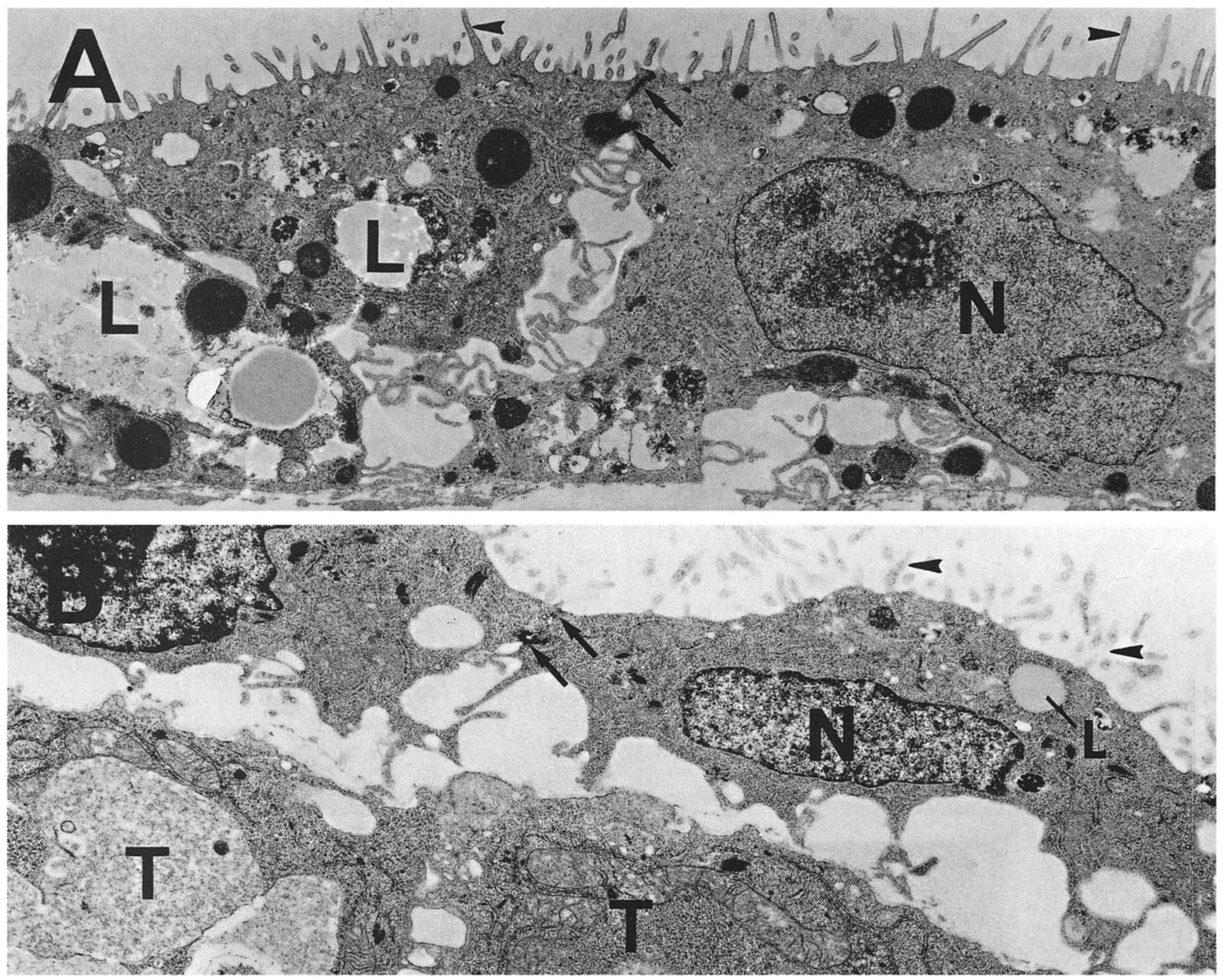

FIG. 5. Electron micrograph of BPE-1 cells at passage 42 compared with the endoderm cells of an in vivo 19-d bovine blastocyst. (A) Cell monolayer showing polarized morphology with characteristic microvilli (arrowheads) and tight junctional unions (arrow) along the apical portion of the roughly cuboidal cells. The STO feeder cells, not shown, are underneath the three BPE-1 cells. $\times 7500$. $(B)$ In vivo endoderm from near the tip of an elongated 19-d bovine blastocyst. The endoderm cells are positioned just underneath the basal membrane of the trophectoderm (T) cells. Note the tight junctional unions with associated desmosomes (arrows) between the endoderm cells and the microvilli at the cell membrane facing the blastocoel cavity. $\times 9450$. N, Nucleus; L, lipid vacuole.

Overall, the BPE-1 cell line was substantially similar to the CE$2 \mathrm{~B}$ cell line previously isolated from a blastocyst produced by IVF (Talbot et al., 2000a). The BPE-1 cells were similar to the CE-2B cells in ultrastructural features, with the exception that BPE-1 cells examined did not have the numerous and robust Golgi complexes that were the striking feature of the CE-2B cells. In this way, the BPE-1 cells appeared more like the bovine endoderm cells analyzed from an in vivo 19-d filamentous bovine blastocyst (Fig. 5). The BPE-1 cells were perhaps most similar to CE-2B cells in cell and colony morphology, growth rate, and transferrin secretion. Besides transferrin, the BPE-1 cells appeared to produce several other serum proteins as was previously shown to be a characteristic of the CE-2B cell line (Talbot et al., 2000a) and of visceral endoderm cells in general (Janzen et al., 1982; Young and Klein, 1983; Shi et al., 1985). It will be of interest to analyze the secreted proteins produced by the BPE-1 cell line in comparison with the CE-2B cell line by 2 -D gel electrophoresis to see what difference may exist between them. Differences in gene and protein expression may in

FIG. 6. Electron micrograph of BPE-1 cell monolayer at passage 42. (A) Tight junctional area (arrows) and desmosomes (arrowheads) connect the BPE-1 cells together. Note the microvilli (mv) at the apical surface of the cells. $\times 18,900$. $(B)$ Higher magnification showing the rough endoplasmic reticulum (RER) that was often prominent in the cells. $\times 94,500$. N, Nucleus; L, lipid vacuole; M, mitochondria. 


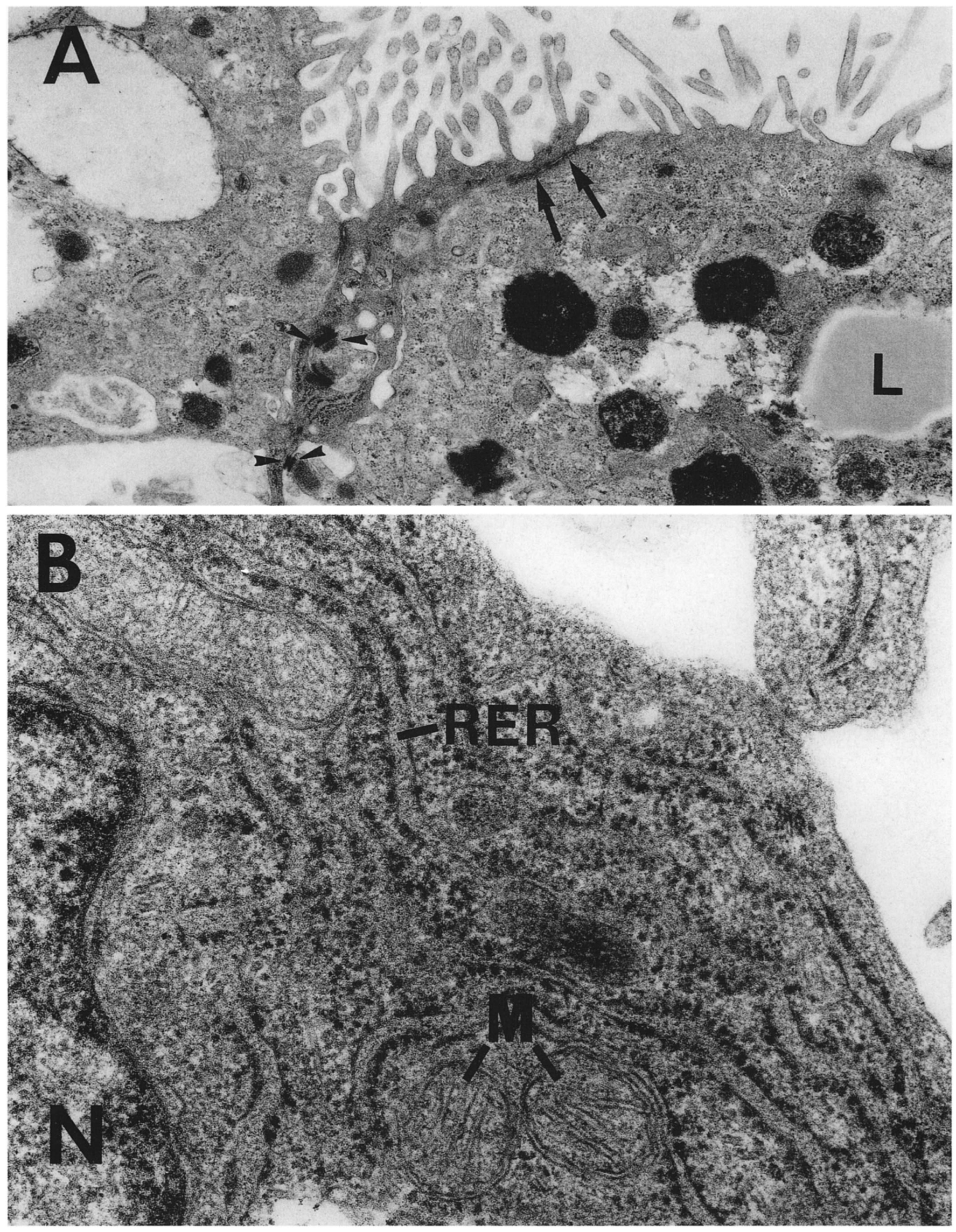



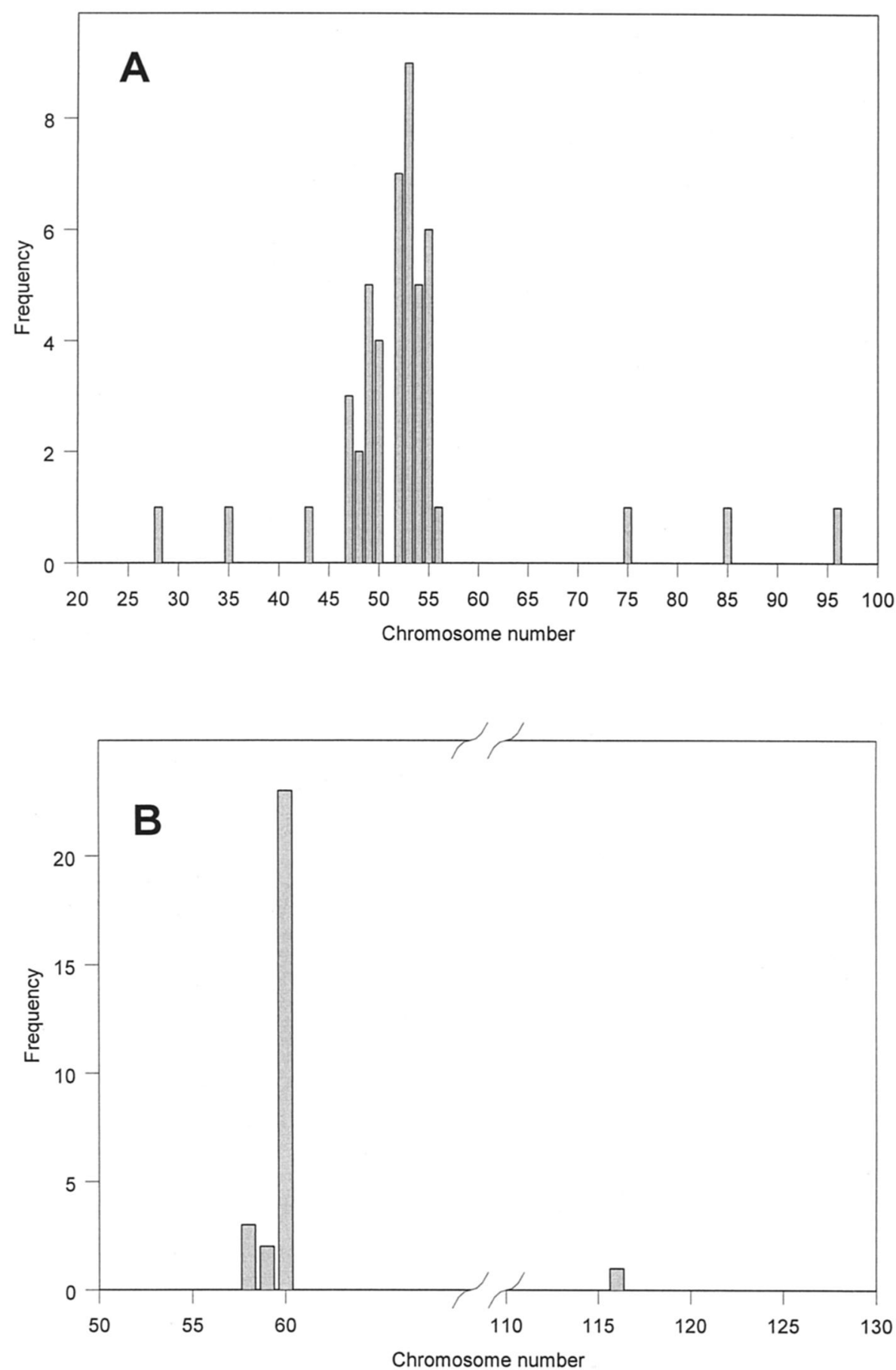

FIG. 7. Karyotype analysis of BPE-1 cells. (A) Forty-eight metaphase spreads of BPE-1 cells were prepared and counted at passage 41. $(B)$ Thirty metaphase spreads from a bovine fetal fibroblast culture at passage 4 were prepared and counted as a comparative control.

part reflect deficiencies resulting from the lack of paternally imprinted genes that are expected to be absent in the BPE-1 cells (Kharroubi et al., 2001). However, the evaluation of several cell lines independently derived from parthenogenetic and IVF embryos will be necessary to establish what differences simply reflect variations in cell population selection, i.e., growth and survival, in response to adapting to the in vitro environment.

The BPE-1 cell line was hypodiploid on the basis that most of the metaphase spreads assayed contained fewer than the normal complement of 60 chromosomes. Also, the level of heterogeneity in the chromosomal content of BPE-1 is not unexpected for an extensively passaged cell line, but it may indicate that the karyotype of the BPE-1 cell population has not stabilized, as described for other cell lines, even after greater than 40 passages in culture (Freshney, 1994; Mamaeva, 1998). The endoderm of the initial cell culture presumably arose from cells that diploidized early on after parthe- 

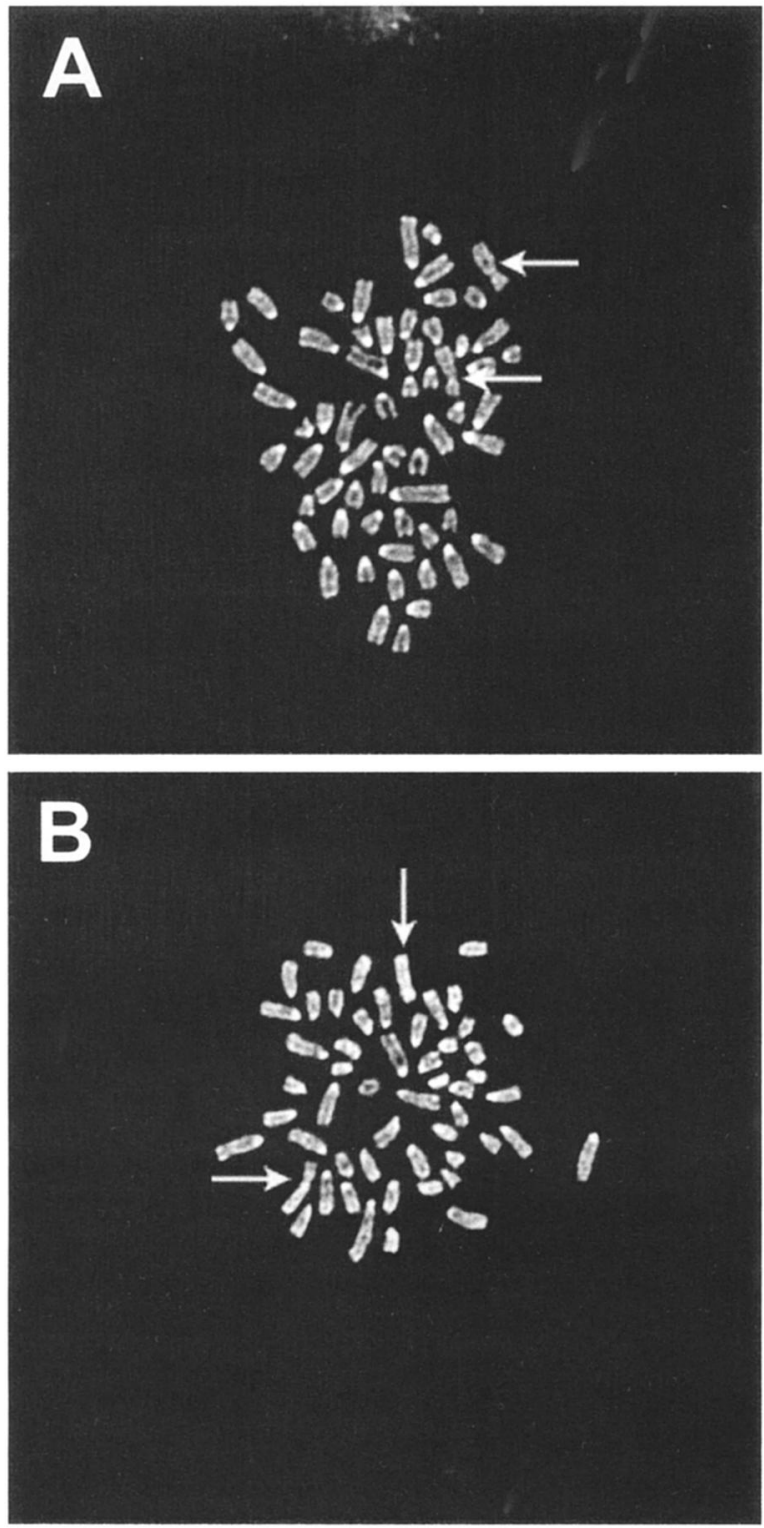

Fic. 8. Normal diploid metaphase spread prepared from bovine fetal fibroblast cells at passage $4(A)$ in comparison with the hypodiploid metaphase spread of a BPE-1 cell at passage $41(B)$. Note the two X-chromosomes in the BPE-1 and BFF karyotypes (arrows) BFF, bovine fetal fibroblast.

nogenetic activation or from an egg that did not extrude a second polar body. Karyotype studies of parthenogenetic bovine blastocysts that were produced in a similar manner (i.e., sequential ionomycin and 6-dimethylaminopurine treatment) have shown that most of the resulting blastocysts contain cells that are not all diploid but are instead polyploid, with mixoploidy being in evidence (Winger et al., 1997; De La Fuente and King, 1998). Thus, it is possible that the BPE-1 cell culture was initially of mixed ploidy, but that diploid endoderm cells that were present in the primary explant culture thrived and out competed cells of abnormal ploidy. Subsequent drift in the population to a hypodiploid state probably resulted during the extensive passage of the culture (Freshney, 1994; Mamaeva, 1998). However, it is possible the BPE-1 cell line was generated from haploid or near-haploid endoderm cells existing in the primary parthenogenetic blastocyst explant culture, although haploidy in bovine parthenogenotes appears to occur rarely (Winger et al., 1997). Although hypodipoid and near-haploid cell lines exist, it has been found that over extensive passage, a compensatory shift takes place in the cell population to a hyperdiploid state, presumably to correct for partial or complete monosomies (Freshney, 1994; Mamaeva, 1998).

A previously observed distinct morphological feature of primary cultures of porcine and bovine visceral endoderm cells (Talbot et al., 1993, 1995) was a phase-contrast-dark, web-like pattern of unidentified cytoskeletal-like elements that ran through the cytoplasm and encircled the nucleus. A similar web-like cytoskeletal array was also a prominent morphological feature in the cells of a visceral endoderm cell line, CE-2B, previously isolated from a bovine embryo produced by IVF (Talbot et al., 2000a). The immunocytochemical analysis for actin and tubulin defined their spatial arrangement in the BPE-1 cells and showed that the microtubule network (tubulin) corresponded with the phase-contrast-dark elements observed in the cells. In comparison, the microtubule networks in the CE-2B cell line and in the endoderm cells lining the interior of an 11-d porcine embryo were more coalesced and, therefore, seemingly even more robust in appearance. This feature may reflect the microtubule network's major role in transport of endosomes in endocytotic or transcytotic transport of nutrients through the yolk sac epithelium (Starling et al., 1983; Beckman et al., 1997).

The BPE-1 parthenogenetic cell line and similar cell lines that could be created in the future may help define deficiencies in "reprogramming" that lead to developmental abnormalities in NT pregnancies (Hill et al., 2000; De Sousa et al., 2001; Hashizume et al., 2002). In comparison with NT embryos and the successful reprogramming of the donor somatic nucleus, IVF-derived endoderm represents the best case comparative developmental potential (often successful), and the parthenogenote-derived endoderm represents the worst case comparative developmental potential (never successful). Thus, analysis of endoderm cell lines derived from IVF embryos (i.e., bovine embryos carrying a normal maternal and paternal genetic complement) or parthenogenotes (maternal genetic complement only) might allow the definition of many genetic and phenotypic differences that predispose parthenogenetic embryos to early death (Surani and Barton, 1983; Fukui et al., 1992; Boediono and Suzuki, 1994; Susko-Parrish et al., 1994; Loi et al., 1998). Although analyses of genetic imprinting would be complicated by a nondiploid chromosome complement (loss of a chromosome could be interpreted as a loss of induced state), diploid cell lines are usually genetically stable at early passage levels (Freshney, 1994; Talbot et al., 2000a). That in vitro models can yield reliable gene expression profiles is supported by the finding that in fibroblast cultures derived from uniparental fetuses (androgenotes or parthenogenotes), the parent of the origin expression profile of several maternally imprinted and several paternally imprinted genes was maintained over 30 cell generations in culture (Kharroubi et al., 2001). Aberrant alterations in gene expression arising from the lack of normal imprinted gene complements in parthenogenetic endoderm (Surani and Barton, 1983; Surani et al., 1990) might therefore provide mechanistic candidates for pregnancy failure that can be similarly found in NT endoderm epigenetic gene expression, but, in the case of NT, results from ineffective reestablishment of genetic imprint status or 


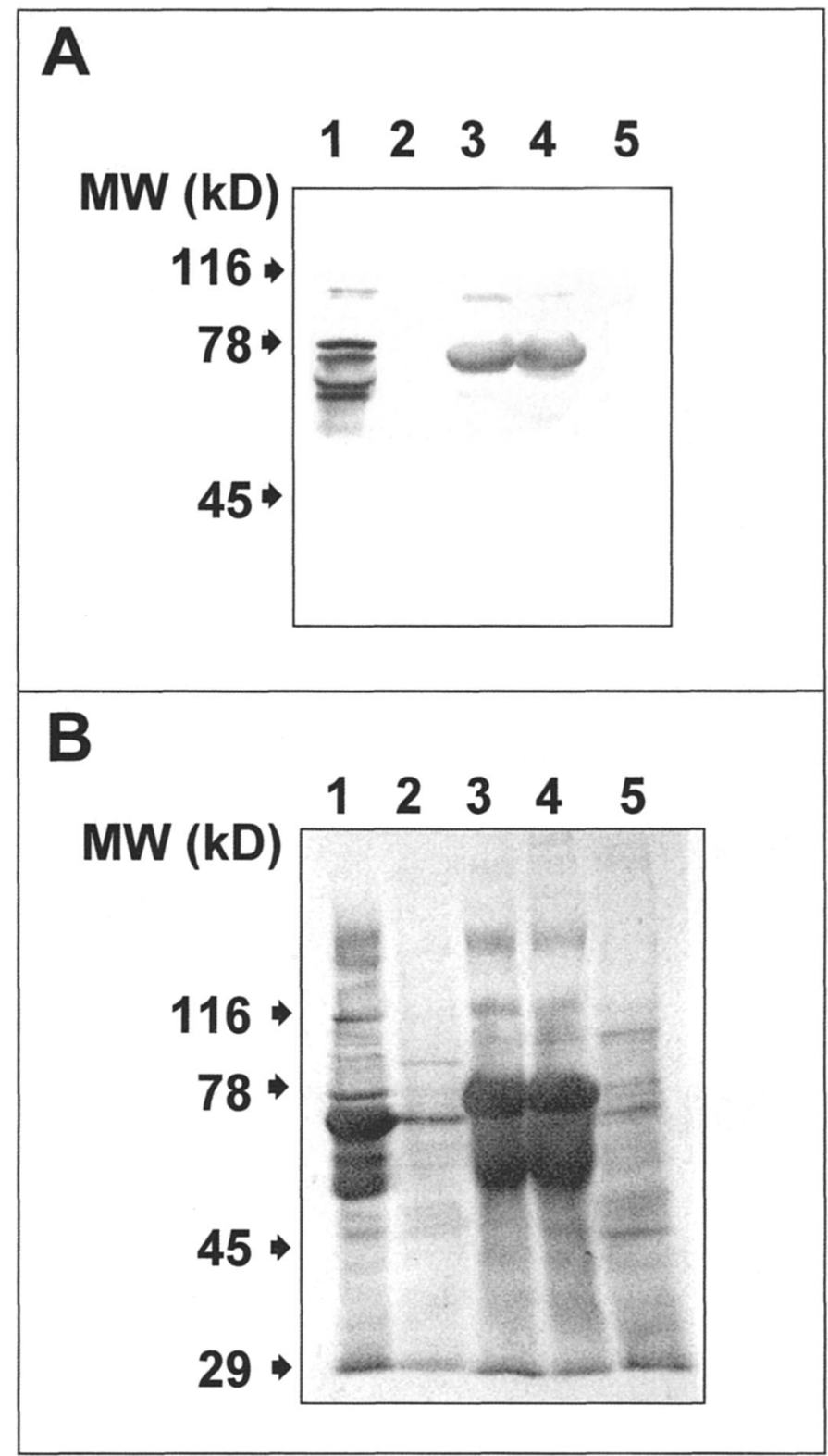

FIG. 9. The SDS-PAGE and Western blot of BPE-1 conditioned medium demonstrating the expression of serum-like protein profile and the specific expression of transferrin. Separating gel of $1 \times \mathrm{CM}(72 \mathrm{~h})$ was stained for total protein with Coomassie Blue $(B)$, and the corresponding Western blot $(A)$ was probed with antibovine transferrin. Lane 1, $0.1 \mu \mathrm{l}$ adult bovine serum; lane 2, STO feeder cell CM; lane 3, BPE-1 CM at passage 42; lane 4, CM from CE-2B bovine endoderm cell line; lane 5, CM from a bovine parthenogenetic trophectoderm cell culture SDS-PAGE, sodium dodecyl sulfate-polyacrylamide gel electrophoresis; CM, conditioned medium.

methylation status (Humpherys et al., 2002; Cezar et al., 2003; Santos et al., 2003).

In summary, the presented work demonstrates the establishment of a parthenogenetic visceral endoderm cell line, and it is assumed that this could be readily repeated to create numerous cell lines for comparative purposes. Besides the "standard" culture conditions, the in vitro endoderm model enables the experimental manipulation of the cell's environment (e.g., addition of specific growth factors, hormones, metabolites, etc.) to ask how gene expression responses are changed in themselves and in comparison with other cell lines. It is anticipated that functional comparisons with IVF- or NT-de- rived visceral endoderm cell cultures will yield information relevant to the yolk sac's role in supporting the growth and survival of periimplantation bovine embryos.

\section{ACKNOWLEDGMENTS}

We thank Drs. Julie Long, Kurt Zuelke, Sally E. Johnson, Kevin D. Wells, and John M. Talbot for their helpful editorial and scientific comments on the manuscript. We also thank Mr. Paul Graninger for technical assistance in tissue culture, metaphase spread preparation, and karyotype enumeration, Ms. Amy Shannon for technical assistance with immunoblotting, and Ms. Olga M. Ocon for assisting with IFN- $\tau$ antiviral assays. 


\section{REFERENCES}

Adamson, E. D.; Strickland, S.; Tu, M., et al. A teratocarcinoma-derived endoderm stem cell line (1H5) that can differentiate into extra-embryonic endoderm cell types. Differentiation 29:68-76; 1985.

Beckman, D. A.; Lloyd, J. B.; Brent, R. L. Investigations into mechanisms of amino acid supply to the rat embryo using whole-embryo culture. Int. J. Dev. Biol. 41:315-318; 1997.

Boediono, A.; Suzuki, T. Pregnancies after transfer of aggregated parthenogenetic bovine activated oocytes. Theriogenology 41:166; 1994.

Carlson, B. M. Patten's foundations of embryology. New York, NY: McGrawHill; 1981:197-200.

Cezar, G. G.; Bartolomei, M. S.; Forsberg, E. J., et al. Genome-wide epigenetic alterations in cloned bovine fetuses. Biol. Reprod. 68:1009-1014; 2003.

Chang, M. C. Development of bovine blastocyst with a note on implantation. Anat. Rec. 113:43-161; 1952

De La Fuente, R.; King W. A. Developmental consequences of karyokinesis without cytokinesis during the first mitotic cell cycle of bovine parthenotes. Biol. Reprod. 58:952-962; 1998.

De Sousa, P. A.; King, T.; Harkness, L., et al. Evaluation of gestional deficiencies in cloned sheep fetuses and placentae. Biol. Reprod. 65:23-30; 2001.

Freshney, R. I. Culture of animal cells. 3rd ed. New York, NY: Wiley-Liss; 1994:12, 254.

Fukui, Y.; Sawai, K.; Furudate, M., et al. Parthenogenetic development of bovine oocytes treated with ethanol and cytochalasin B after in vitro maturation. Mol. Reprod. Dev. 33:357-362; 1992.

Hagemann, L. J.; Peterson, A. J.; Weilert, L. L., et al. In vitro and early development of sheep gynogenones and putative androgenones. Mol. Reprod. Dev. 50:154-162; 1998.

Hashizume, K.; Ishiwata, H.; Kizaki, K., et al. Implantation and placental development in somatic cell clone recipient cows. Cloning Stem Cells 4:197-209; 2002.

Hill, J. R.; Burghardt, R. C.; Jones, K., et al. Evidence for placental abnormalities as the major cause of mortality in first-trimester somatic cell cloned bovine fetuses. Biol. Reprod. 63:1787-1794; 2000.

Humpherys, D.; Eggan, K.; Akutsu, H., et al. Abnormal gene expression in cloned mice derived from embryonic stem cell and cumulus cell nuclei. Proc. Natl. Acad. Sci. USA 99:12889-12894; 2002.

Inoue, K.; Kodha, T.; Lee, J., et al. Faithful expression of imprinted genes in cloned mice. Science 295:297; 2002.

Janzen, R. G.; Mably, E. R.; Tamaoki, T., et al. Synthesis of alpha-fetoprotein by the pre-implantation and post-implantation bovine embryo. J. Reprod. Fertil. 65:105-110; 1982.

Kadokawa, Y.; Kato, Y.; Eguchi, G. Cell lineage analysis of the primitive and visceral endoderm of mouse embryos cultured in vitro. Cell Differ. 21:69-76; 1987.

Kaufman, M. H.; Robertson, E. J.; Handyside, A. H., et al. Establishment of pluripotential cell lines from haploid mouse embryos. J. Embryol. Exp. Morphol. 73:249-261; 1983.

Kharroubi, A. B.; Piras, G.; Stewart, C. L. DNA demethylation reactivates a subset of imprinted genes in uniparental mouse embryonic fibroblasts. J. Biol. Chem. 276:8674-8680; 2001.

Laemmli, U. K. Cleavage of structural proteins during the assembly of the head of bacteriophage T4. Nature 277:680-685; 1970.

Loi, P.; Ledda, S.; Fulka, J., Jr., et al. Development of parthenogenetic and cloned ovine embryos: effect of activation protocols. Biol. Reprod. 58:1177-1187; 1998.

Mamaeva, S. E. Karyotypic evolution of cells in culture: a new concept. Int. Rev. Cytol. 178:1-40; 1998.

Mossman, H. W. Vertebrate fetal membranes. New Brunswick, NJ: Rutgers University Press; 1987:279-291.
Mummery, C. L.; van Achterberg, T. A. E.; van den Eijnden-van Raaji, A. J. M., et al. Visceral-endoderm-like cell lines induce differentiation of murine P19 embryonal carcinoma cells. Differentiation 46:51-60; 1991.

Niimi, G.; Usuda, N.; Shinzato, M., et al. A light and electron microscopic study of the mouse visceral yolk sac endodermal cells in the middle and late embryonic periods, showing the possibility of definitive erythropoiesis. Ann. Anat. 184:425-429; 2002.

Pera, M. F.; Blasco-Lafita, M. J.; Mills, J. Cultured stem-cells from human testicular teratomas: the nature of human embryonal carcinoma, and its comparison with two types of yolk-sac carcinoma. Int. J. Cancer 40:334-343; 1987

Rober . R. M.; Imakawa, K.; Niwano, Y., et al. Interferon production by the preimplanation sh , embryo. J. Interferon Res. 9:175-187; 1989.

Rüsse, I.; Sinowatz, F.; I iter, L., et al. Development of the yolk sac of ruminants (sheep and cattle). Anat. Histol. Embryol. 21:324-347; 1992.

Santos, F.; Zakhartchenko, V.; Stojkovic, M., et al. Epigenetic marking correlates with developmental potential in cloned bovine preimplantation embryos. Curr. Biol. 13:1116-1121; 2003.

Shi, W. K.; Hopkins, B.; Thompson, S., et al. Synthesis of apolipoproteins, alphafoetoprotein, albumin, and transferrin by the human foetal yolk sac and other foetal organs. J. Embryol. Exp. Morphol. 85:191-206; 1985

Starling, D.; Duncan, R.; Lloyd, J. B. The role of microtubules in pinocytosis. Inhibition of fluid-phase pinocytosis in rat visceral yolk sac by mitoclasic and related agents. Cell Biol. Int. Rep. 7:593-602; 1983.

Surani, M. A. H.; Barton, S. C. Development of gynogenetic eggs in the mouse: implications for parthenogenetic embryos. Science 222:1034-1036; 1983.

Surani, M. A. H., Kothary, R., Allen, N. D., et al. Genome imprinting and development in the mouse. Development (Suppl.):89-98; 1990.

Susko-Parrish, J. L.; Leibfried-Rutledge, M. L.; Northey, D. L., et al. Inhibition of protein kinases after an induced calcium transient causes transition of bovine oocytes to embryonic cycles without meiotic completion. Dev. Biol. 166:729-739; 1994.

Tada, T.; Takagi, N. Early development and X-chromosome inactivation in mouse parthenogenetic embryos. Mol. Reprod. Dev. 31:20-27; 1992.

Talbot, N. C.; Caperna, T. J.; Edwards, J. L., et al. Bovine blastocyst-derived trophectoderm and endoderm cell cultures: interferon-tau and transferrin expression as respective in vitro markers. Biol. Reprod. 62:235-247; 2000a.

Talbot, N. C.; Garrett, W. M.; Caperna, T. J. 2003. Analysis of the expression of aquaporin-1 and -9 in pig liver tissue: comparison with rat liver tissue. Cells Tissues Organs 174:17-28; 2003.

Talbot, N. C.; Powell, A.; Garrett, W., et al. Ultrastructural and karyotypic examination of in vitro produced bovine embryos developed in the sheep uterus. Tissue Cell 32:9-27; 2000b.

Talbot, N. C.; Powell, A. M.; Rexroad, C. E., Jr. In vitro pluripotency of epiblasts derived from bovine blastocysts. Mol. Reprod. Dev. 42:35-52; 1995

Talbot, N. C.; Rexroad, C. E., Jr.; Pursel, V. G., et al. Culturing the epiblast cells of the pig blastocyst. In Vitro Cell. Dev. Biol. 29A:543-554; 1993.

Walter, G.; Intek, A.; Wobus, A. M., et al. Serological characterization of a pluripotent mouse embryonal stem cell line, two transformed derivatives, and an endoderm-like cell line. Cell Differ. 15:147-151; 1984.

Winger, Q. A., De La Fuente, R., King, W. A., et al. Bovine parthenogenesis is characterized by abnormal chromosomal complements: implications for maternal and paternal co-dependence during early bovine development. Dev. Genet. 21:160-166; 1997.

Young, M. F.; Klein, N. W. Synthesis of serum proteins by cultures of chick embryo yolk sac endodermal cells. Dev. Biol. 100:50-58; 1983. 